\title{
STUDIES IN THE ADAPTATION OF AN ARTIFICIAL FOOD TO HUMAN MILK*
}

H. J. GERSTENBERGER, M.D., H. D. HASKINS, M.D.

H. H. McGREGOR, Ph.D., ANd H. O. RUH, M.D.

CLEVELAND, 0 .

Introduction by H. J. Gerstenberger

In 1910, the physiologist, Friedenthal ${ }^{1}$ again picked up the threads which led to the ideal set up by the pediatrist Biedert a generation ago; namely, to the production of an artificial milk similar in all its important characteristics to the best food for the human infant, namcly, breast milk. By not getting the results that it had expected from mixtures which took into consideration the quantities of protein, lactose, and fat in human milk, the pediatric world became discouraged and considered the production of an artificial human milk that would give good practical results a hopeless task. Friedenthal gathered courage for another attempt for the solution of this important and interesting problem from the fact that the salt content and the physical-chemical characteristics of human milk had been entirely neglected, and also from the conviction that these were important, if not the most important individual factors to be considered in the making of an artificial food that was to be similar to breast milk and which would give satisfactory results. Müller and Schloss, ${ }^{2,4}$ and Helbich ${ }^{3}$ had also independently of Friedenthal begun with the attempt to come closer to the composition of breast milk. They received their stimulus from Finkelstein's theory of the injuriousness of the whey of cow's milk. Their first object, therefore, was to modify by reduction the deleterious

* Submitted for publication July 15, 1915.

* From the Babies' Dispensary and Hospital, the Departments of Pediatrics, Chemistry and Biochemistry of Western Reserve University, and from the Walker-Gordon Laboratory, Cleveland, Ohio.

* For the apparatus, the materials and help used in making G-R milk, we are indebted to the Walker-Gordon Laboratory, Cleveland, Ohio.

* Presented at the Annual Meeting of the American Pediatric Society, Lakewood, N. J., May 24, 1915.

1. Friedenthal, H.: Ueber die Eigenschaften künstlicher Milchsera und ueber die Herstellung eines künstlichen Menschenmilchersatzes, Zentralbl. f. Physiol., 1910 , xxiv, 687.

2. Müller, Erich, and Schloss, Ernst: Die Versuche zur Anpassung der Kuhmilch an die Frauenmilch zu Zwecken der Säuglingsernährung, Jahrb. f. Kinderh., 1914, $1 \mathrm{xxx}, 42$.

3. Helbich, H.: Die Bedeutung der Molkenreduktion für die Ernährıng junger Säuglinge, Jahrb. f. Kinderh., 1910, 1xxi, 655.

4. Schloss, E.: Ueber Säuglingsernährung, Berlin, 1912, S. Karger. 
whey of cow's milk. They, however, encouraged by the favorable results that they had had in their institution with high fat milks, also attempted to simulate more accurately than heretofore the composition of breast milk. Schloss stated in his address at the Königsberger meeting of the Gesellschaft für Kinderheilkunde in 1910, that he and his co-workers were convinced that the road that they were following would ultimately lead to the solution of the problem of the producton of an adequate artificial food. So while they had visions of accomplishments along this direction, Friedenthal ${ }^{1}$ had already, from theoretical grounds, worked out a plan according to which a more complete adaptation of an artificial food to breast milk could be obtained. In his article Friedenthal states that artificial woman's milk ought to contain 0.7 per cent. casein, 0.8 per cent. albumin and globulin, 7 to 8 per cent. milk sugar, $3 \mathrm{I} / 2$ per cent. fat, ash, a freezing point of -0.56 , degrees electrical conductivity of $23 \times 10^{-4}$ at 18 degrees, neutral reaction ( $\mathrm{H}$ Ion Content $5 \times 10^{-8}$ ) besides traces of nuclein, lecithin and albuminoids, and have the proper energy content. Friedenthal further states in a later contribution (note 20) that the correlation of the salt components is of greater importance than is the total ash content.

Schloss ${ }^{2,4}$ then tried out Friedenthal's milk but did not get satistory results and, therefore, again modified this product. Schloss, in order to have more accurate data as to the ash composition of human and cow's milk, himself made analysis. The analyses on breast milk made by Schloss are of great value because he was the first to use samples of twenty-four hour quantities of breast milk for his determinations. In addition, he took samples of a mixed milk composed of full twenty-four hour specimens of eight women. The analyses that he got differed from those accepted up to that time. His further work, therefore, was based on the more dependable, analytical figures obtained by himself in this manner. Schloss, ${ }^{*}$ however, felt that the poor results that he had obtained with Friedenthal's milk were due mainly to the lactose content, and he therefore replaced this with the preparation containing maltose and dextrin, and oftentimes in addition cornstarch. He also added a proprietary preparation of sodium caseinate to bring up the protein content.

By making these changes Schloss really left the road that leads to the complete adaptation of an artificial food to woman's milk, and, therefore, Friedenthal's milk, although based on less accurate analytical data, comes closer to the accomplishment of this ideal than does Schloss' milk.

Bahrdt ${ }^{5}$ reports favorably his experience with the feeding of this milk in eighty-one cases. He states that at least among the children

5. Bahrdt, H., Bamberg, Edelstein, Hornemann: Ernährungsversuche mit Friedenthalscher Milch, Ztschr. f. Kinderh., Orig., 1914, x, 303. 
of the Kaiserin Augusta Victoria-Haus, Friedenthal's milk promises better results than those obtained with mixtures of simple dilutions with carbohydrate additions. Although the analytical and the metabolism work presented in his article has been seemingly justly criticized by Müller and Schloss, ${ }^{2}$ this fact does not necessarily disprove the good clinical results obtained by Bahrdt. It was the writer's impression when he in 1913 personally conversed with Bahrdt regarding his results with Friedenthal's milk that this food did really give good results and did mean a distinct addition to our means. Both in the personal conversation and in the article which Bahrdt published later, he emphasized the nearly universal presence of vomiting and marked spitting and of dyspeptic stools in most of the infants fed with this food.

This fact, together with the interesting and important experimental data obtained by Huldschinsky, ${ }^{6}$ namely, (1) that the stomach of infants fed with human milk contains very small amounts of the low volatile fatty acids; (2) that the stomach of infants fed with cow's milk contains three to six times as much; (3) that the amount of the low volatile fatty acids found in the stomach of babies fed with cow's milk corresponds to the amount of fat in the milk; and (4) that the formation of these free low volatile fatty acids in the stomach of a healthy infant fed on cow's milk is caused by the splitting of the glycerids of these acids by a ferment, and that the type of the former low volatile fatty acids found in the stomach corresponds to the type existing in a preformed state in the milk fat, led me to believe that probably the qualitative differences between cow's milk fat and breast milk fat were to blame, in a large measure at least, for the excessive spitting, vomiting, and dyspeptic stools.

It is a recognized fact that cow's milk fat contains many more of the low volatile fatty acids than does breast milk fat (10 per cent. to 1.6 per cent. Langstein and $\mathrm{Meyer}^{7}$ ), and there are those-Bokai, ${ }^{8}$ Bahrdt, ${ }^{9}$ Czerny, ${ }^{10}$ and others-who believe that the low volatile fatty acids play an important part in the production of acute nutritional dis-

6. Huldschinsky, K. Untersuchungen über die Pathogenese der Verdauungsstörungen im Säuglingsalter; Mitteilung, V.: Ztschr. f. Kinderh., Orig., 1912, III, 366.

7. Langstein-Meyer: Säuglingsernährung und Säuglingsstoffwechsel, Ed. 2 and 3 , pp. 22, 23, 29 and 133 .

8. Bokai, A.: Experimentelle Beiträge zur Kenntniss der Darmbewegungen. C. Ueber die Wirkung einiger Bestandteile der Fäces auf die Darmbewegungen, Arch. f. exper. Path. u. Pharmokol., 1888, xxiv, 153.

9. Bahrdt, H., and McLean, Stafford: Untersuchungen über die Pathogenese der Verdauungsstörungen im Säuglingsalter; VIII. Mitteilung, Ztschr. f. Kinderh., Orig., 1914, xi, 143.

10. Czerny-Keller: Des Kindes Ernährung Ernährungsstörungen und Ernährungstherapie, Abt. 7, p. 137, Franz Deuticke, Wien, 1909. 
a fat that would give a refraction, saponification number, ReichertMeissl number, iodin number, and Polenske number, very close to that of the fat of breast milk. It was decided, therefore, to use these data in the experimental and clinical work as soon as the homogenizer had arrived. While we were waiting, Niemann's" article on "Ueber die Möglichkeit einer Fettanerreichung der Säuglingsnahrung," appeared. He evidently had in mind the same goal as I, but had decided to reach it over another route, namely, over that of washed butter. Inasmuch as he claimed in his article to get an adequate removal of the low fatty acids from the butter by washing it with water, and also by vigorous stirring of a heated mixture an adequate and permanent emulsion of fat, together with Drs. Haskins and Ruh, I set myself at work to carry out Niemann's suggestion regarding the freeing of butter from the low volatile fatty acids with the idea of adding this fat to Friedenthal's milk. We hoped that by heating and vigorous stirring we were to accomplish the same permanent emulsification that Niemann ${ }^{13}$ had obtained, with what results will be stated later.

The work of Funk ${ }^{14}$ regarding vitamines, and his theory on the etiology of rickets, the work of Osborne and Mendel, ${ }^{15}$ Peiser $^{16}$ and Bruning ${ }^{17}$ on the growth value of the various food substances, especially fats, the work of Hess $^{18}$ on scurvy, the findings of Bahrdt, ${ }^{7}$ Edelstein and Csonka ${ }^{19}$ regarding the iron content of human and cow's

13. Niemann, Albert: Ueber die Möglichkeit einer Fettanreicherung der Säuglingsnahrung, Jahrb. f. Kinderh., 1914, Ixxix, 274.

14. Funk, Casimir: The Nitrogenous Constitutents of Lime-Juice, Biochem. Jour., vii, 81 ; Forschritte der experimentellen Beriberiforschung in den Jahren 1911 bis 1913, München. med. Wchnschr., 1913, 1x, 1997; An Attempt to Estimate the Vitamine-Fraction in Milk, Biochem. Jour., 1913, vii, 211; Studien ueber das Wachstum, Mitteilung 1. Das Wachstum auf vitaminhaltiger und vitaminfreier Nahrung, Hoppe-Seylers Ztschr. f. physiol. Chem., .1913, 1xxxviii, 352; Ueber die physiologische Bedeutung gewisser bisher unbekannter Nahrungsbestandteile der Vitamine, Ergebn. d. Physiol., 1913, xiii, 124.

15. Osborne, Thos. B., and Mendel, Lafayette, B.: Mendel, Lafayette V.: Viewpoints in the Study of Growth, Biochem. Bull., 1914, iii; The Nutritive Significance of Different Kinds of Foodstuffs, Med. Rec., New York, 1914, 1xxxv, 737. Osborne, Thos. B., and Mendel, Lafayette B.: The Influence of Butter-Fat on Growth, Jour. Biol. Chem., 1913, xvi, 423; The Influence of Codliver Oil and Some Other Fats on Growth, Jour. Biol. Chem., 1914, xvii, 401; Feeding Experiments with Fat-Free Food Mixtures, Jour. Biol. Chem., 1912, xii, 81; Further Observations on the Influence of Natural Fats Upon Growth, Jour. Biol. Chem., 1915, xx, 379.

16. Peiser, J.: Ueber Fettaustausch in der Säuglingsernährung, Berl. klin. Wchnschr., 1914, li, 1165.

17. Brüning, Hermann: Untersuchungen ueber das Wachstum von Tieren jenseits der Säuglingsperiode bei verschiedenartiger künstlicher Ernährung, Jahrb. f. Kinderh., 1914, 1xxix, 305.

18. Hess, Alfred F., and Fish, Mildred: Infantile Scurvy: The Blood, the Blood Vessels, and the Diet, Am. Jour. Dis. Child., 1914, viii, 385.

19. Edelstein, F., and Csonka, F. v.: Ueber den Eisengehalt der Kuhmilch, Biochem. Ztschr., 1912, xxxviii, 14. 
milk, the theories of Friedenthal ${ }^{20}$ regarding the need of sufficient "Bausteine der Kernstoffe," are all of the greatest importance to the solution of the problem of a more perfect and complete adaptation of an artificial food to human breast milk, and must receive full consideration. While various mixtures have been prepared with the object of taking into account the work of some of the authors just mentioned, the present presentation aims to confine itself mainly to the analytical, bacteriologic, physical, mechanical, practical and few clinical data obtained in the work with the preparation of our so-called G-R milk No. 2, which represents nothing more or less than Friedenthal's milk in which butter fat has been replaced with another fat having about the same per cent. of low volatile fatty acids as breast milk has, and having in addition other characteristics more similar to breast milk fat than to cow milk's fat. Some analytical data regarding the fats of G-R milk Nos. 3, 4, and 5 will also be presented as well as the experience of the authors with butter washed according to Niemann.

\section{PART I}

\section{Homogenization}

A. Homogenizer.-The machine procured for us by the Walker-Gordon Laboratory was a Manton-Gaulin machine with a pressure capacity for 500 kilograms. Its liquid capacity was found by us to be about 200 c.c. The pressure used by us was 250 kilograms.

B. Technic Carried Out in the Homogenization of Various Mixtures.-(a) Fats - butter fat, lard, cocoanut oil, cocoa butter, codliver oil: The various fats were weighed out in sterile granite dishes. The dishes with the fats were put into a steam jacketed kettle of hot to boiling water until the contents became liquid. The pans containing the fat were then emptied and drained into a larger steam jacketed kettle into which all the other ingredients of the food had been mixed. The amount of fat remaining in the pans after thorough draining was so small as to be negligible.

(b) Sugar: The lactose was at first added in the form of a sugar solution of 19 to 21 per cent. Later on it was found more convenient and more accurate to simply weigh the lactose in the sterile granite pan and dump it into the common mixing kettle.

(c) Salts: The salts were accurately weighed in a glass receptacle. The contents of the receptacle were dumped into the mixing vat and the particles adhering to the inside of the dish rinsed out with distilled water. This amount, of course, was deducted from the batch of distilled water measured for the entire quantity.

(d) Skimmed milk: The amount of required skimmed milk was added to the mixture in cubic centimeters. To save time different granite pitchers were carefully marked for definite amounts.

(e) Water: The amount of required distilled water, less 200 c.c. for the capacity of the machine, was measured in cubic centimeters and added to the

20. Friedenthal, H.: Ueber Säuglingsernährung nach physiologischen Grundsätzen mit Friedenthal'scher Kindermilch und Gemüsepulvern, Berl. klin. Wchnschr., 1914, li, 727. 
mixture. To save time different granite pitchers were carefully marked for definite amounts.

( $f$ ) Quantity: The amount most frequently used by us for an individual batch was 30 liters.

(g) Mixing: 1, mixing before homogenization: Inasmuch as the largest steam jacketed kettle at our disposal could comfortably hold but 20 liters, the fat, salt, sugar, skimmed milk, and enough water to make about a total of 20 liters were put into the vat, stirred vigorously, and brought by steam heat to a temperature of $150 \mathrm{~F}$. In order to avoid an excessive loss of the fat, which would occur if the mixture were allowed to go through the homogenizer undisturbed, it was necessary to keep up a constant stirring. Soon it was possible to develop a special technic in this respect that enabled a constant mixture of the fat with the other parts of the batch. At a time when nearly all of the 20 liters had passed through the homogenizer, the remaining water was poured into the vat and run through the machine.

Recently another larger receptacle has been used for mixing all of the milk and water at one time. Out of this receptacle the milk and water mixture is run in desired amounts into the steam jacketed lettle containing the sugar, the fat, and salts. The use of this extra receptacle has lessened the time and made the practical part of the work more simple.

2. Mixing after homogenization: From the above, it will be recognized that the first part of the mixture going through the homogenizer is much more concentrated than the second part. Therefore, it is essential that a mixture of all these parts be brought about before bottling. This was managed by pouring from one can to another.

Recently we have been pouring all of the homogenized milk into the same receptacle in which the water and skimmed milk had been mixed before homogenization. This also is more simple and saves time.

(h) Temperature: The temperature of the mixture is brought to $150 \mathrm{~F}$. before it is allowed to go through the homogenizer. It is easy to keep the batch at this temperature by regulating the steam going through the kettle and the cold skimmed milk and water coming out of the large mixing receptacle. The temperature of the milk rises about 8 to 10 degrees in the process of homogenization. During the filling, bottling, capping, etc., it drops again to about 145 to 135 , and it usually enters the ice box at this temperature.

(i) Bottling: From the large mixing vat the milk is run into a small enamel bottling machine and filled into bottles sterilized in an autoclave. The bottles are then capped with a simple cap and with a cover cap and placed in the ice box.

( $j$ ) Cleanliness: All of the bottles, dishes, and utensils are sterilized in the autoclave. The mixing vat is sterilized by allowing the water to boil in it. The homogenizer is cleansed and, in all probability, sterilized by running this boiling water through it just before the homogenization of the milk is to take place. This procedure also gives one the opportunity of testing the machine for any leaks.

No more than the usual precautions are taken with the packing, shipping, etc., of the fats, sugar, skimmed milk and water.

The liands of the individuals making the milk are simply cleaned with soap and water.

The authors are aware that Friedenthal requires that the skimmed milk be not heated. They have, however, felt that for their present work, at least, it would be better and safer practically to pasteurize the finished product. In all probability there will be no difficulty when the time comes to add at least a big part of the skimmed milk in a raw state to the finished product. 


\section{PART II}

\section{Butter Fat}

A. Creamery Butter.-(a) Cold water washing: Fresh, sweet creamery butter, in packed and in granular form, was vigorously and thoroughly rubbed and washed with some eight to ten changes of cold water. The acidity of the wash water was determined by the use of phenolphthalein and a tenth-normal sodium hydroxid solution. The amount of acids washed out was so small as to be insignificant.

(b) Hot water washing: Assuming that hot water might give better results, the butter was melted and the fat separated from the curd by passing through a cheesecloth. The filtered liquid was poured, together with hot distilled water, into a large bottle. The mixture was kept hot by placing the bottle in a waterbath. After thorough shaking the bottle was replaced in the water-bath and the fat allowed to separate from the wash water, which was then siphoned off for determination of its acidity. Four washings were carried out with each batch. Records of the amounts of tenth-normal sodium hydroxid required to neutralize the acids of the combined wash waters have been lost, but it can be stated that the amounts were so small as to be absolutely insignificant, and were, in all probability, due to the presence of a small amount of free acids and also caseinogen, which was being dissolved out. Burr and Weise ${ }^{21}$ report that fresh butter fat always has a small amount of free fatty acids in amounts that require for $10 \mathrm{gm}$. of butter 0.6 to 1.4 c.c. tenth-normal sodium hydroxid solution. The best proof that the reduction in the low volatile fatty acid content of the butter was very insignificant is the finding for the same of a Reichert-Meissl number of 28 , practically the same obtained in ordinary unwashed butter.

Grimmer $^{22}$ in his abstract of Niemann's article, criticizes Niemann's procedure and states that it is impossible to wash the low volatile fatty acids out of the butter because they are present in it in the form of glycerids, just as the higher acids are, and are, therefore, not free. In other words, Grimmer's statement corresponds with our findings.

(c) Alcohol washing: $263 \mathrm{gm}$. of clear butter fat were removed from one pound of fresh creamery butter, 255 c.c. of redistilled alcohol were added and the materials brought to boiling under thorough mixing. The mixture was then cooled to a low temperature and the alcoholic liquid decanted from the solid fat. The solid fat was then heated until the alcohol in it had evaporated. The residue weighed $252 \mathrm{gm}$. The Reichert-Meissl value of this residue fat was 4.0 , and the iodin value 38.9 . The addition of $10 \mathrm{gm}$. of sesame oil to $100 \mathrm{gm}$. to this alcohol washed fat gave an iodin value of 44.3 . In other words, it is possible to remove the glycerids of the low volatile fatty acids from butter fat by washing with hot alcohol. The same plan has been carried out by Hunziger and Spitzer. ${ }^{23}$

(d) Emulsification according to Niemann: Both the cold water and the hot water washed butter fat were added to Friedenthal's milk in amounts to bring the fat content up to 4.5 per cent. The mixture was brought to the boiling point and was vigorously stirred, as directed by Niemann. The results were not the same as those obtained by Niemann, for the fat on standing and cooling rose to the surface. Niemann, however, used an entirely different mixture,

21. Burr, A., and Weise, H.: Ueber den Gehalt frischen Butterfettes an freien Fettsäuren und flüchtigen Fettsäuren, Molkereizeitung, Hildesheim, 1914, No. 16.

22. Grimmer, W.: Die Arbeiten auf dem Gebiete der Milchwissenschraft und Molkereipraxis im Jahre, 1914, I Semester, Monatschr. f. Kinderh., Referate, 1915, xiv, 81.

23. Hunziker, O. F., and Spitzer, G.: A Study of the Chemical Composition of Butterfat, and its Relation to the Composition of Butter, Proc. Indiana Acad. Sc., $\mathrm{xxv}, 15$. 
which contained $50 \mathrm{gm}$. of mondamin (cornstarch) to each liter of milk, and this addition to his milk mixture was, in all probability, responsible for the difference in our results.

(e) Clinical data: Owing to the fact that the homogenizer was a very large machine used for the homogenization of large quantities of cream and was too large and unhandy for our work, and owing also to the climatic conditions that existed at that time - heat, August, 1914 - only a few older, well babies were put on the milk simply to get a rough idea how the children would take it and react to it; that is, whether there would be an improvement over Bahrdt's ${ }^{5}$ experiences or not. Only three older infants were put on Friedenthal's milk with cold water washed butter and two on Friedenthal's milk with hot water washed butter. Two of the former reacted with thin, yellow stools in increased numbers and one vomited severely. One of the latter reacted in the same manner. The mothers of these children were not enthusiastic about our giving their babies this "new milk" under such conditions, and we, therefore, because of this and the further reasons for limiting the number of babies in the first place, decided to discontinue our clinical investigations until the arrival of cooler weather and of the smaller homogenizer, which the Walker-Gordon Company was having made for our use. The impression that we gained from this very meager experience with Friedenthal's milk and water washed butter was that there was no improvement over the results obtained by Bahrdt with the regular Friedenthal's milk.

B. Process Butter.-Process butter was considered by us because of its cheapness and also because of the fact that it surely had ample chance to decompose and so have many of the low volatile fatty acids in a free state, which condition would enable us to remove the latter by washing the butter with water. The work with this material was soon dropped because of our inability to rid it from the very disagreeable odor.

\section{PART III}

\section{Mixed Fats, Animal and Vegetable}

A. General Statement.-As stated in the introduction, our main object was to find a fat or combination of fats that would be more similar to breast milk fat than cow's milk fat, especially regarding the low fatty acid content, and to see whether a substitution of such a fat for the cow's milk fat in Friedenthal's milk might not improve this milk and represent a further step in the more complete adaptation of artificial food to human milk.

B. Experimental Data.-The accompanying table by Arnold ${ }^{12}$ (Table 1) directed our attention to the use of lard and cocoanut oil:

TABLE 1

FROM ARNOLD'S WORK, "UFBER FRAUENMILCHFIETT"

\begin{tabular}{lcccc} 
& & & Woman's \\
Refraction ............. & 35.1 & \multicolumn{1}{c}{ Lard } & Mixture & Milk Fat, I \\
Saponification number. & 259.0 & 47.7 & 47.65 & 47.6 \\
Reichert-Meissl number & 9.0 & 197.5 & 206.1 & 206.08 \\
Iodin number........... & 8.5 & 53.0 & 3.0 & 2.65 \\
Polenske number...... & 15.8 & 0.15 & 46.77 & 46.25 \\
& & 1.65 & 1.65
\end{tabular}

For many reasons it seemed worth while to try to make cod-liver oil a part of this fat combination. In order to make such a mixture more palatable cocoa butter was added. We, therefore, prepared four batches of fats in the following manner:

No. 2. Lard 86.00 per cent., cocoanut oil 14 per cent.

No. 3. Lard 74.88 per cent., cocoanut oil 14 per cent., codliver oil 11.11 per cent. 
No. 4. Lard 63.78 per cent., cocoanut oil 14 per cent., codliver oil 11.11 per cent., cocoa butter 11.11 per cent. cent.

No. 5. Lard 74.88 per cent., cocoanut oil 14 per cent., cocoa butter 11.11 per

It was our intention to use all four of these, but for practical reasons, after having found out that infants would take any one of them, we decided-to limit our experiences for the beginning to G-R milk No. 2 .

Table 2 gives first, the character numbers of the individual fats; second, the character numbers of the fats of G-R milk Nos. 2, 3, 4, and 5, obtained by calculation on the basis of the character numbers actually found for the individual fats (the individual fats were mixed by heating at 60 ) ; third, the character numbers of the fats mixed in the same proportion as they were mixed in the milk; fourth, the character numbers for the mixture of lard and cocoanut oil in the proportion as they were used in G-R milk No. 2, and heated for the same period of time as required to extract the fat from G-R milk No. 2; and fifth, the character numbers of the fat extracted from G-R milk No. 2.

\begin{tabular}{|c|c|c|c|c|}
\hline \multirow[t]{2}{*}{2.} & DAta CONCERI & VARIOUS & \multicolumn{2}{|c|}{ FATS UsÉd } \\
\hline & Reichert-Meissl & Polenske & Iodin & Saponification \\
\hline Lard .... & 0.08 & 0.49 & 63.07 & 195.5 \\
\hline Cocoanut oil & 6.436 & 13.69 & 8.836 & 259.5 \\
\hline Cocoa butter .......... & 0.34 & 0.30 & 36.35 & 196.4 \\
\hline $\begin{array}{c}\text { Codliver oil ........... } \\
\text { Mixed fats: } \\
\text { (Same proportions) }\end{array}$ & 0.27 & 0.315 & 170.0 & 189.9 \\
\hline As Milk II (calculated). & 0.9698 & 2.337 & 55.45 & 204.5 \\
\hline $\begin{array}{l}\text { As Milk II found } . . . . \\
\text { As Milk II found } * . . .\end{array}$ & 1.638 & 1.231 & 55.46 & 206.8 \\
\hline Fat from Milk II.... & 2.72 & 1.2 & 50.0 & 206.0 \\
\hline As Milk III (calculated) & 0.9914 & 2.318 & 66.24 & 203.8 \\
\hline $\begin{array}{l}\text { As Milk III found ...... } \\
\text { (Same proportions) }\end{array}$ & 2.09 & 1.288 & 67.5 & 205.1 \\
\hline As Milk IV (calculated) & 1.188 & 2.297 & 63.14 & 204.0 \\
\hline $\begin{array}{l}\text { As Milk IV found } \ldots . . . \\
\text { (Same proportions) }\end{array}$ & 2.127 & 1.498 & 64.49 & 205.4 \\
\hline As Milk V (calculated). & 0.8128 & 2.318 & 52.52 & 204.6 \\
\hline Milk V & 97 & & & \\
\hline
\end{tabular}

* Fats in same proportion as in Milk II heated with ether for same period of time as required to extract fat from milk.

Table 2 reveals the fact that it is possible to calculate the iodin and the saponification values of mixtures of fats before or after homogenization in milk, from a consideration of these values in the individual fats. The data with equal clearness show that the ReichertMeissl and Polenske numbers may not be so calculated, but that the mixing of the fats produces a change in the relative amounts of soluble and insoluble fatty acids that will volatilize with steam in the time required for the determination. It is noteworthy that the total amount of the volatile fatty acids is not greatly changed, for the sum of Reichert-Meissl and Polenske numbers as found is in each case approximately the same as the sum of the calculated values. This variation is not now understood and further work will be done to determine the cause of the change in value. 
The slight increase of 0.2 in the Reichert-Meissl number of the fat from G-R milk No. 2 over the mixture of the same fats in the same proportions and heated for the same period of time as required to extract the fat from G-R milk, is probably due to the 0.4 per cent. of butter fat present in the skimmed milk, as can be seen from Table 5 .

By comparing the character numbers as given in Table 2 for G-R milk No. 2 with Arnold's figures for his mixture and for his woman's milk fat No. 1, it will be seen that the Reichert-Meissl and saponification numbers are nearly identical; that there is a slight difference between the Polenske numbers, and a decided difference between the iodin numbers. The difference between the iodin numbers is due to the high iodin value of the batch of lard used in our work ( $\mathrm{G}-\mathrm{R}$ milk, lard 63.07; Arnold, lard 53.0). By rearranging the mixture we could have procured an iodin value for the $G-R$ milk fat which would have been closer to Arnold's figures for woman's milk fat, but by doing so we would have changed the Reichert-Meissl and the saponification numbers; but as the Reichert-Miessl value seemś of first importance to us, we decided to continue to use this mixture without any further change, and it is, of course, probable that a fair increase in the iodin number above that found in woman's milk fat is of no great importance.

The following figures given by Arnold ${ }^{12}$ for his analysis of another woman's milk fat (Frauenmilchfett No. 2),

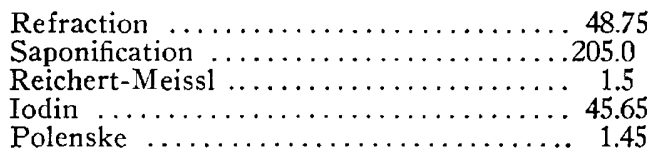

show, as one, of course, would expect, that fat from milk coming from different women will show variances in the character numbers of their respective fats.

Merkel $^{24}$ reports the following as character numbers of a butter made from the cream of a four-day quantity of milk from a wetnurse:

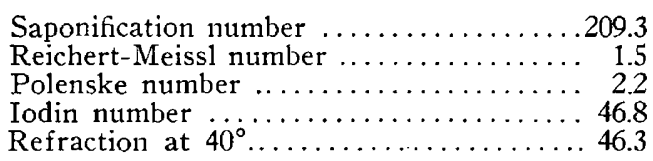

Table 3 shows that by making use of tallow-which one might imagine from Osborne and Mendel's ${ }^{15}$ work, might even have an added value over lard-in the fat mixture, a greater resemblance as regards iodin numbers can be obtained.

24. Werkel, Eduard: Zur Kenntnis des Frauenmilchfettes, Pharm. Zentralhalle, 1912, liii, 495. 


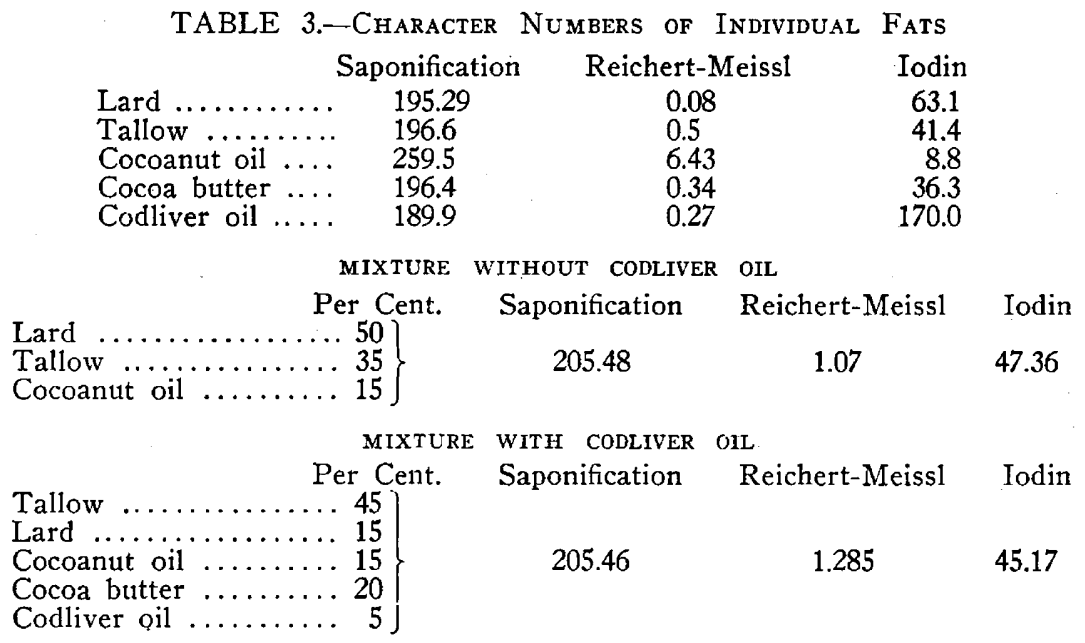

Table 4 shows the materials used for a typical batch of G-R milk No. 2. The table is analyzed to show the origin of the various contributing substances:

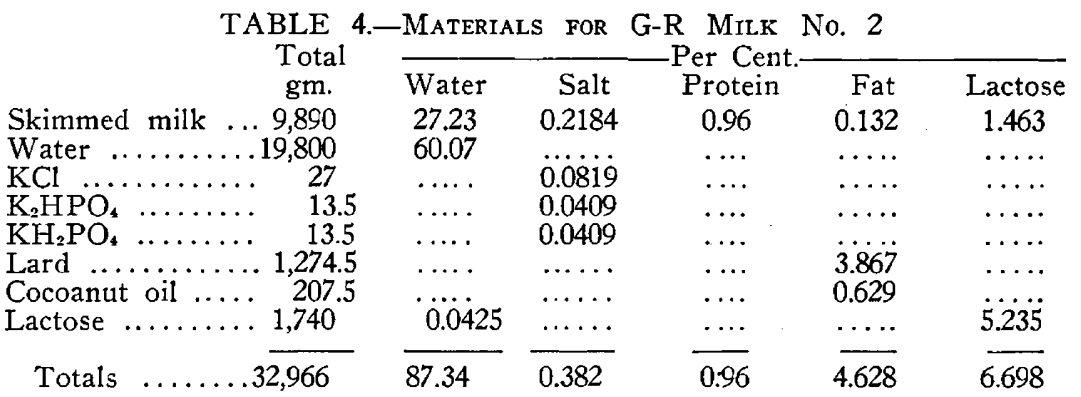

The distribution of the substances from the skimmed milk shown in Table 4 is based on the analysis of the milk used, shown in Table 5.

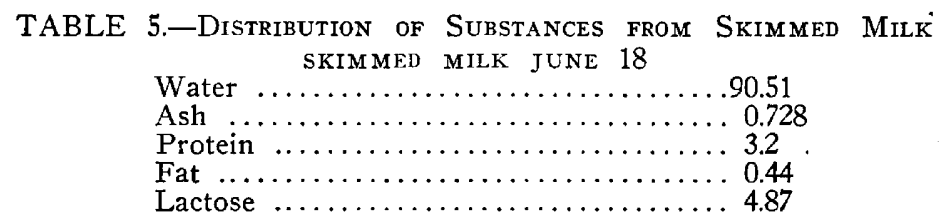

The composition and characters of the G-R milk No. 2 prepared from the batch given in Table 4 , as determined by analysis, are summarized in Table 6.

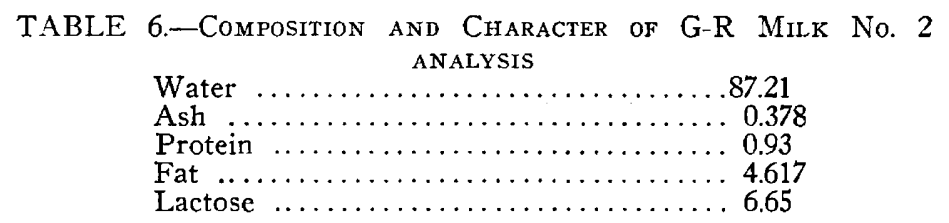


General characters: Specific gravity $15.5^{\circ}, 1.032$; specific conductivity $20^{\circ}$, $3.41 \times 10^{-3}$ recip. ohms; freezing point depression $0.618^{\circ}$; caloric value per kg., 739.6 cal.

Characteristics of fat content: Size fat globules, 0.2-1 micron; brownian movement vigorous; Reichert-Meissl value, 2.72; Polenske number, 1.2; iodin number, 55.0; saponification number, 206.0.

That the milk maintained the same general composition may be judged from the accompanying analyses made at different periods (Table 7).

Table 7.-Analysis of G-R Milk No. 2, at Different Periods

\begin{tabular}{|c|c|c|c|c|}
\hline & May 18 & May 20 & June 5 & June 18 \\
\hline Water & 86.8 & 87.14 & 87.44 & 87.21 \\
\hline Ash & 0.43 & 0.37 & 0.37 & 0.378 \\
\hline Protein & 1.1 & 0.97 & 0.91 & 0.93 \\
\hline Fat $\ldots$. & $\begin{array}{r}4.52 \\
7.07\end{array}$ & 4.58 & 4.6 & 4.617 \\
\hline cose & & 6.63 & & \\
\hline
\end{tabular}

The somewhat low protein and lactose content is due, in a part at least, to the fact that the milk was added as grams instead of c.c.

\begin{tabular}{|c|c|c|c|c|}
\hline TABLE & $\begin{array}{l}\text { 8.-BACTERIAL } \\
\text { Date }\end{array}$ & COUNTS FOR & $\begin{array}{c}\text { SKIMMED AND } \\
\text { Count }\end{array}$ & $\begin{array}{l}\text { Finished Milks } \\
\text { Skim, Count }\end{array}$ \\
\hline & Date 6 & $\mathrm{No} 2 \mathrm{II}$ & Count & Skim, Count \\
\hline & $\begin{array}{ll}\text { May } 6 \\
\text { May }\end{array}$ & No. 2 III & Sterile & …... \\
\hline & May 6 & No. 2 IV & Sterile & …... \\
\hline & May 6 & No. $2 \mathrm{~V}$ & Sterile & ....... \\
\hline & May 12 & No. 2 II & 3,100 & ...... \\
\hline & May 12 & No. 2 IIII & 5,000 & \\
\hline & May 12 & No. 2 IV & 16,100 & 9,850 \\
\hline & May 19 & No. 2 & 1,850 & \\
\hline & May 20 & No. 2 & 4,500 & $55,300 *$ \\
\hline & May 21 & No. 2 & 6,000 & 91,000 * \\
\hline & May 22 & No. 2 & Sterile & 11,300 * \\
\hline & May 24 & No. 2 & Sterile & $19,700 *$ \\
\hline & May 25 & No. 2 & Sterile & \\
\hline & May 26 & No. 2 & Sterile & 39,000 * \\
\hline & May 27 & No. 2 & Sterile & $5,500 *$ \\
\hline & May 31 & No. 2 & Sterile & ....... \\
\hline & May 29 & No. 2 & 4,900 & $\cdots \cdots$ \\
\hline & June 2 & No. 2 & 1,000 & 2400 \\
\hline & June 4 & No. 2 & Sterile & 7,200 \\
\hline & June 5 & No. 2 & 300 & 8,400 \\
\hline & June 7 & No. 2 & Sterile & 157,200 \\
\hline & June 9 & No. 2 & Sterile & 6,800 \\
\hline & June 11 & No. 2 & 1,700 & 4,500 \\
\hline & June 12 & No. 2 & 9,000 & 2,000 \\
\hline & June 14 & No. 2 & 3,100 & 42,000 \\
\hline & June 16 & No. 2 & Sterile & 70,000 \\
\hline & June 19 & No. 2 & 200 & 3,200 \\
\hline & June 20 & No. 2 & 700 & 400 \\
\hline & June 25 & No. 2 & 200 & 300 \\
\hline & June 26 & No. 2 & 300 & 2,700 \\
\hline
\end{tabular}

Table 8 gives the bacteriological counts for the skimmed milk and for the finished milks, and shows on the whole very low bacterial counts for the prepared milk. These excellent results are, in all proba- 
bility, due to the fact that, unknowingly, practically the same technic and conditions were established by us as advocated by Ayers and Johnson. ${ }^{25}$

Analytical Methods.-Water, Ash, Protein: The methods used for determin. ing water, ash and protein are those of the A. O. A. C. described in Bulletin 107 of the Department of Agriculture.

Fat: The usual methods for fat extraction and estimation are completely unreliable with homogenized milk of this type. When the Babcock centrifugal method is used a definite separation of fatty from acid layer cannot be obtained. Various determinations were made by the Adams paper coil method, and the following figures obtained on milk that by more accurate analysis was shown to contain 4.5 per cent. of fat: $3.75,3.69,3.34,2.24$ per cent. A modification of the Werner-Schmidt acid method yielded fairly close results, but very great difficulty was experienced in securing a separation of the acid and ether layers. The Roese-Gottlieb process was then employed, and it was found that excellent results can be obtained when low-boiling petroleum ether (35 C.) is used, and the second and third extractions accomplished by inversion, without shaking, of the mixture. The above recorded analyses substantiate the accuracy of this method.

Method of Fat Extraction from Milk: 150 c.c. of milk were diluted with 250 c.c. water, and 9 c.c. of 1 per cent. sulphuric acid added, with constant stirring. A cylindrical cup made from fat-free filter paper was fitted closely into a Buchner funnel and after moistening the paper the acidified mixture was filtered. After normal filtering had ceased, the filtrate was discarded and suction applied until most of the water was removed. This final filtrate was shaken with ether, and the ether subsequently used for the extraction of the fat from the precipitate. The filter paper with precipitate was transferred to a mortar and ground with about $20 \mathrm{gm}$. anhydrous sodium sulphate, when a dry, somewhat waxy porous powder resulted. This powder was placed in a Soxhlet apparatus, where extraction was complete in two hours. The ether was then driven off, or in some cases the ether solution was transferred by pipet to the vessel in which a determination was to be made.

Reichert-Meissl Value: Leffmann and Beam's saponification method was used, and the distillation continued thirty minutes.

Polenske Number: Glycerol saponification was used, and the condenser tubes washed three times with water, then three times with alcohol.

Iodin Number: The Wjis method was used.

Saponification Number: One gm. of the fat was saponified with 5 per cent. potassium hydroxid in specially purified alcohol. It is of importance that the blank determination be heated on the water bath for the same period of time as the regular determinations.

Size of Fat Globules: The value of 0.2 to 1 microns was roughly approximated by the use of Thoma's hemacytometer. The fat globules exhibit remarkable uniformity of size, and all show vigorous brownian movement.

Lactose: The solid lactose used was examined both polarimetrically and by reduction, and found to be 99.2 per cent., $\mathrm{C}_{12} \mathrm{H}_{22} \mathrm{O}_{11} \cdot \mathrm{H}_{2} \mathrm{O}$. Lactose in milk was determined in each case by the polarimeter, using acid mercuric nitrate for precipitation, and estimating the solids by the method of double dilution. To check the polarimetric method, the milk analyzed on June 18 was determined also by the reduction method, using Soxhlet's modification of Fehling's solution, weighing the copper as cupric oxid, and calculating lactose from the

25. Ayers, S. H., and Johnson, W. T., Jr.: Pasteurization in Bottles and the Process of Bottling Hot Pasteurized Milk, Jour. Infect. Dis., 1914, xiv, 217. 
Soxhlet-Wein tables. The results show the absence of any substances in the milk that would vitiate the accuracy of the polarimetric method.

Per cent. lactose by polariscope $\ldots \ldots \ldots \ldots 6.51$
Per cent. lactose by reduction .........6.537

Specific Gravity: Quevenne's lactodensimeter was used at $15.5 \mathrm{C}$.

Conductivity: Conductivity was measured by the Kohlrausch method, using a cell with electrodes about $1 \mathrm{~cm}$. apart and $2.5 \mathrm{~cm}$. in diameter.

Depression of Freezing Point.-The determination was made by the usual method. It is highly important that the temperature of the freezing mixture be not lower than about $-1.5 \mathrm{C}$. as the concentration of the solution by the settling out of ice changes the $f$. p. significantly.

Calorimetry: To determine the heating value, 2 c.c. of milk were accurately weighed in a small combustion cup. This was placed in a desiccator equipped with shelves holding dishes filled with calcium chlorid. Evacuation was accomplished by a water pump, and in twenty-four hours the material had dried and showed no evidence of loss by spattering. The dried milk was then burned in a Parr bomb with 20 atmospheres oxygen pressure. The calculation of heating value from the analysis of milk reported in Table 7 (June 18) closely agrees with the direct calorimetric determination.

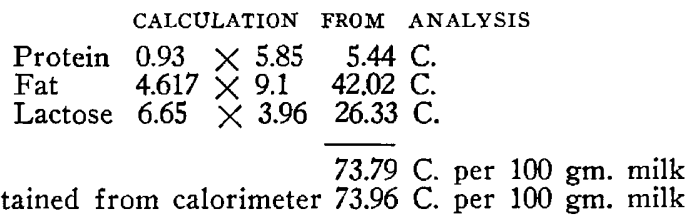

C. Clinical Data.-(a) Vomiting: The clinical experience until now has not been sufficient to be considered worthy of report. It is hoped at a later time to present the clinical results. A statement, however, can be made regarding the degree of vomiting and dyspeptic stools met with so frequently by Bahrdt in his patients fed with Friedenthal's milk prepared with unchanged cow's fat. Of a list of twenty babies, from 1 week to 7 months of age, there was spitting up or slight vomiting in five. In two of these this has disappeared; in a third, the vomiting continues once a day; and in the other two there still exists a slight vomiting. Two other children showed marked vomiting before they were put on the food; the one gradually improved while on the milk, and now does not vomit at all, and the other is a case of pylorospasm which continues to vomit, but which has begun to gain in weight since it has been getting the food.

(b) Stools: Of the twenty children only two showed dyspeptic stools. Two were constipated and passed rather firm, somewhat formed, fatty soap stools. The remainder had what we termed normal stools. These varied in color from a lemon-yellow to an orange-yellow, were of a lard-like, pasty consistency, and contained, in most instances, smaller or larger masses of soft, fatty soaps. Many of the stools changed from a yellow to an olive-green in the diaper.

These few data suffice to prove that the vomiting has been decidedly less and the stools decidedly more normal in our children than they were in Bahrdt's, and we believe that this is due to the removal of the low volatile fatty acids. Whether the fact that the milk was homogenized has anything to do with these better results is impossible to say at the present time. Birk, according to Grulee, ${ }^{26}$ could find no improve-

26. Grulee, Clifford G.: Infant Feeding, W. B. Saunders Co., 1912. 
ment in the children by homogenizing their foods. On the other hand, Lavialle $^{27}$ believes that the homogenization greatly enhances the digestibility of a milk because it offers to the digestive ferments a much larger action surface, and because it causes, by reason of the marked brownian movement, the formation of currents, which are responsible for an active mixing of ferments and foods. Inasmuch as the fat in human milk does not exist in such a fine emulsion as the fat of homogenized milk, it can at least be assumed that a finer division than is present in human milk is not necessary; on the other hand, there is, at present, no reason to believe that any harm is done to the fat or any other constituent of the milk by homogenization, excepting, of course, the effect of the raised temperature on some of the constituents of skimmed milk; and it may be found that homogenization is of greater value in the production of artificial human milk than the mere mixing for which it has been used by us.

(c) Weight: The following figures are given to show that normal or slightly below normal infants made good gains in weight. Eighteen infants, from 1 week to 7 months of age, for a total period of seventy-three weeks, made a total gain of $10,630 \mathrm{gm}$., or an average of $145+\mathrm{gm}$. per week.

D. Economical Data.-Friedenthal's milk made up with a mixture of fats like lard, tallow, cocoa butter, cocoanut oil, cod-liver oil, olive oil, cottonseed oil, sesame oil, and the like, can be produced at a price decidedly lower than when butter freed from a large per cent. of its low fatty acid glycerids is used. The cost of the fat per liter of various combinations with various fats, is as follows :

For a mixture of tallow 40 per cent., lard 10 per cent., cocoanut oil 20 per cent., cocoanut butter 20 per cent., codliver oil 10 per cent. ..............................................30 cents G-R Milk No. 2 ..................................... cents

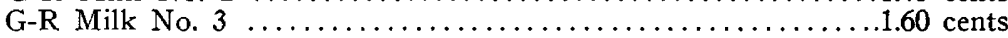

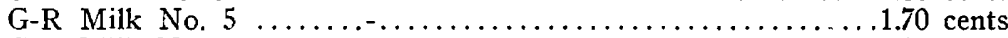

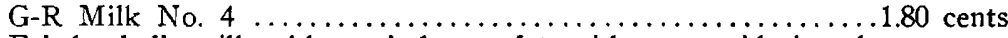
Friedenthal's milk with cow's butter fat, without considering the cost of washing the butter with alcohol..................70 cents

While the production cost of a milk for infants is not of the first importance, yet it is, nevertheless, true that there are many families who cannot get for their infants what they should have simply because of the price, and, therefore, if an adequate food can be prepared at a low cost it is an advantage that is important when it is desired that all families whose infants require it should get it. It is also interesting to think of the economy that would result in a general way by the reduction in the use of the more expensive butter and the increase in the use of fats that are distinctly cheaper.

27. Lavialle, P.: Le mouvement brownien dans le lait homogeneise, Clin. infant., 1913, xi, 490 . 


\section{SUMMARY}

1. By mixing varying proportions of different animal and vegetable fats, it is possible to get a fat that in its Reichert-Meissl number (small per cent. of low volatile fatty acid glycerids), saponification number, iodin number, and other characters, is nearly identical with the fat of human milk, as has previously been shown by Arnold.

2. By replacing in an artificial milk cow's-milk fat with the fat of the above description in an emulsified state (homogenized), a distinct step in advance towards the more complete adaptation of an artificial food to breast milk is made.

3. It is also possible to take into consideration the "growth factors," "vitamine factors," and the like, in choosing the individual fats for an acceptable mixture. This represents a further step in the more complete adaptation of an artificial milk to human milk.

4. The homogenizer represents the important means by which the mixing and emulsification of the fat in the artificial milk is possible. The homogenizer also changes the physical condition of the fat (smaller globules, brownian movement), which may be of advantage.

5. The meager clinical data suffice to show that the infants fed with Friedenthal's milk in which the cow's-milk fat has been replaced by a fat with a low volatile fatty acid glycerid content, similar to that of human milk fat, vomit less and have more normal stools than the children reported by Bahrdt, and fed with Friedenthal's milk containing unchanged cow's-milk fat.

6. Washing butter with cold or hot water does not remove the low volatile fatty acids from butter, except in an insignificant degree.

7. Washing butter with hot alcohol does remove the low fatty acid glycerids to a decided degree.

8. The manufacture of a food like G-R milk can be arranged to give a very low bacteriologic count.

9. The production of milk like G-R milk can be made at a reasonable cost. 